\title{
Middle Pleistocene cold stage climates in the Mediterranean: New evidence from the glacial record
}

\author{
P.D. Hughes ${ }^{\text {a,* }}$, J.C. Woodward ${ }^{\mathrm{a}}$, P.L. Gibbard ${ }^{\mathrm{b}}$ \\ ${ }^{a}$ Geography, School of Environment and Development, The University of Manchester, Manchester M13 9PL, UK \\ ${ }^{\mathrm{b}}$ Cambridge Quaternary, Department of Geography, University of Cambridge, Cambridge CB2 3EN, UK
}

Received 17 August 2006; received in revised form 4 October 2006; accepted 6 October 2006

Available online 15 November 2006

Editor: H. Elderfield

\begin{abstract}
A major reduction in summer temperatures during a Middle Pleistocene glacial cycle caused the most extensive glaciation recorded in the Mediterranean region. Glaciers in the mountains of Greece formed during marine isotope stage (MIS) 12 (474000427000 years BP) under climatic conditions characterised by mean summer temperatures at least $11^{\circ} \mathrm{C}$ cooler than today and annual precipitation of $\leq 2300 \mathrm{~mm}$ at the equilibrium line altitude $(1741 \mathrm{~m}$ a.s.1.). This represents the coldest mean summer temperatures recorded in Greece during at least the last 430000 years. Later Pleistocene glaciations (MIS 6 and 5d-2) were characterised by warmer summer temperatures and higher annual precipitation.
\end{abstract}

(C) 2006 Elsevier B.V. All rights reserved.

Keywords: Glaciers; Palaeoclimate; Middle Pleistocene; Mediterranean; Greece

\section{Introduction}

The mountains of the Mediterranean were glaciated on multiple occasions during the Pleistocene [1-5] and the glacial record offers new insights into the nature of cold stage climates in this region. Glaciers are closely related to climate [6] and glacial geomorphological records offer evidence of palaeoclimatic conditions in high mountain regions during Pleistocene cold stages, where other sources of data are commonly absent.

The uplands of the Mediterranean are thought to have been particularly important centres of biotic refugia. The mountainous peninsulas of southern Europe provided

\footnotetext{
* Corresponding author.

E-mail address: philip.hughes@manchester.ac.uk (P.D. Hughes).
}

refugia for temperate biota during Quaternary cold stages when northern Europe and the Alps were covered by ice sheets and permafrost, and the lowland areas of the Mediterranean were characterised by cold and dry steppe [7]. In the Balkans, this is thought to be responsible for genetic diversity with a richness of endemic species [8,9] and pollen records from long lacustrine sequences confirm that the mountains of this region were a refugial area for temperate tree taxa through multiple glacial cycles [10].

The glacial succession in Greece is now one of the best-dated in Europe since recent studies have applied Useries methods to date secondary carbonates within Pleistocene tills to develop a new regional geochronology and chronostratigraphy $[3,4]$. These papers argue that the oldest glacial deposits formed during the Skamnellian 
Table 1

Chronostratigraphy, geochronology and relative-age stratigraphy of the glacial succession in the Pindus Mountains, Greece [4]

\section{Unit Geomorphological characteristics Geochronology U-series ages of secondary Age of host glacial units} calcites within glacial deposits (years).

3 Small cirque moraines and relict rock glaciers. Lowest elevation: $>1800 \mathrm{~m}$ a.s.l.

[Cirque glaciers and rock glaciers]

Glacier area: $3.9 \mathrm{~km}^{2}$

Mean ELA: 2174 m a.s.1.

2 Well-defined arcuate moraines in midvalley positions. Lowest elevation: $c$.

$1500 \mathrm{~m}$ a.s.1.

[Cirque and valley glaciers]

Glacier area: $21.3 \mathrm{~km}^{2}$ Mean ELA: $1862 \mathrm{~m}$ a.s.l.

1 Less well-defined, but extensive, moraines $>350,000$ [ $\times 6$ samples] in lower valley positions. Weathered tills

with thick and well-developed soils.

Lowest elevation: $c .850 \mathrm{~m}$ a.s.l.

[Ice fields, extensive valley glaciers

and some cirque glaciers]

Glacier area: $59.3 \mathrm{~km}^{2}$

Mean ELA: 1741 m a.s.1.

\section{Glacial deposits have not been dated}

directly. Alluvial units associated

with the last major phase of

glaciation, down stream of glaciated

areas on Mount Tymphi, have been

dated to $25000 \pm 2,000$ years

(mean of 5 dates using

U-series and ESR) $[25,26]$.

$121731(125530 \pm 4202)$

$118450(119818 \pm 9249)$

$109116(110198 \pm 4107)$
These deposits are correlated with the
glacial cycle and MIS $5 \mathrm{~d}-2$
(Weichselian/Würmian). The precise

timing of the local last glacial maximum

appears to predate $25000 \pm 2000$ years. The

interval between $30000-25000$ years has

been suggested for the last local glacier

maximum in Greece [19].

The oldest secondary carbonates correlate

with MIS 5e. The glacial units are correlated

with MIS 6 (later Saalian).

The oldest secondary carbonates are beyond the range of U-series dating (>350 000 years).

The oldest secondary carbonates are

correlated with MIS 11, although it is possible

that they are older. Until further evidence

becomes available the best correlation for the

glacial units is with MIS 12 (Elsterian).
Pindus

Soil

Tymphian Stage

characteristics

PDI: 7.8-9.0

U-series dates from secondary carbonates (calcite) within glacial stratigraphical units on Mount Tymphi. The oldest secondary carbonate ages represent minimum ages for the host glacial deposits Since secondary carbonates appear to have formed during interglacials or interstadials, the glacial deposits are likely to have formed during the cold stage immediately prior to the oldest phase of secondary carbonate formation. [Soil PDIs $=$ Soil profile development indices]. 


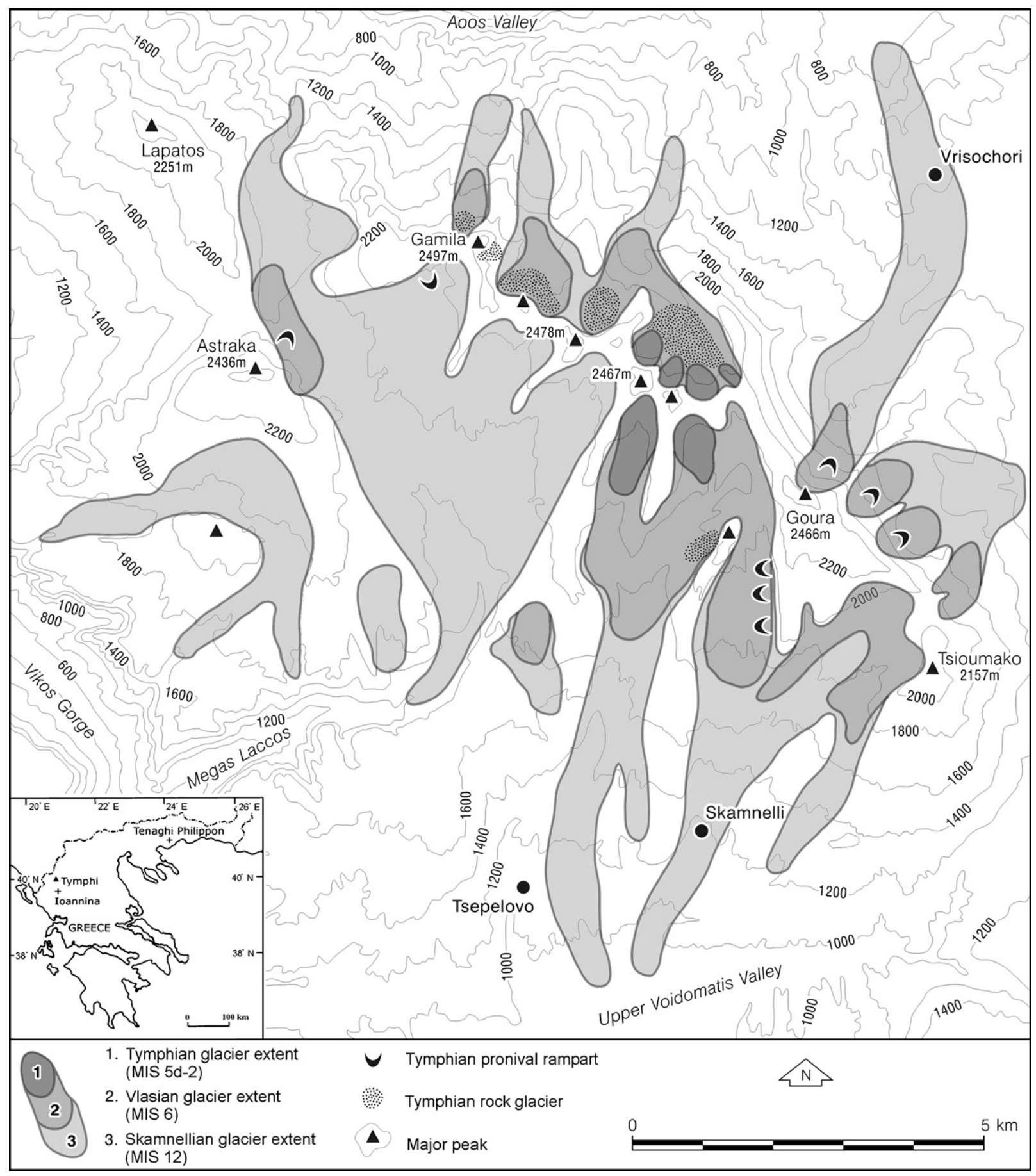

Fig. 1. Pleistocene glacier extent on Mount Tymphi in the Pindus Mountains, northwest Greece.

Stage (MIS 12, 427000-474000 years [11]). As the Useries ages within these glacial deposits exceed the range of this technique (350000 years - Table 1), it is possible that the Skamnellian Stage deposits are older than MIS 12. However, MIS 12 was characterised by the most extensive ice cover of the Middle-Late Pleistocene in northern and eastern Europe during the Elsterian Stage [12] and MIS 12 is correlated with the most extreme cold stage interval recorded in the long pollen sequence at Tenaghi Philippon in NE Greece [13]. The next recorded 


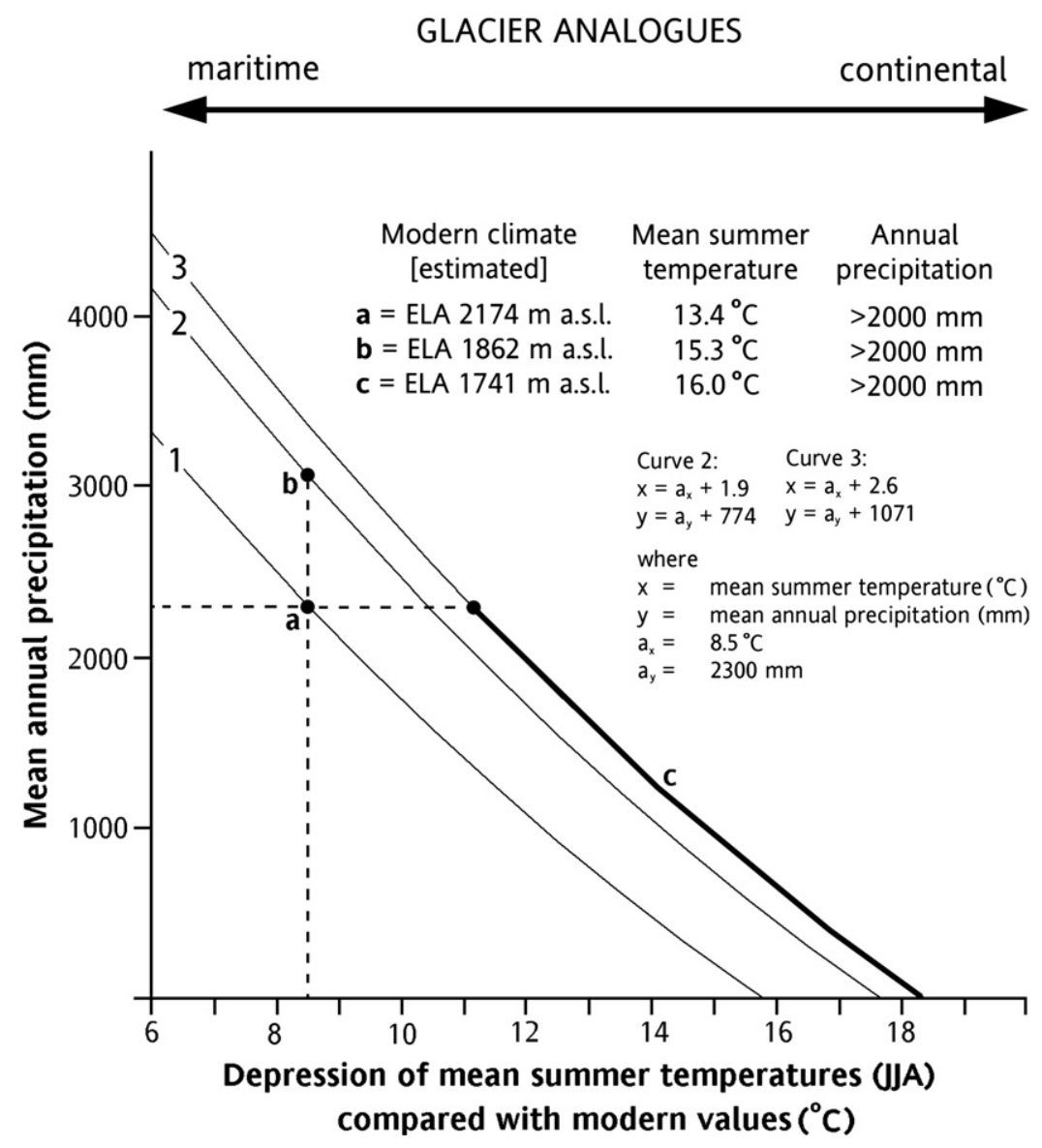

Fig. 2. Potential temperature-precipitation combination curves for different Pleistocene cold stage glacier maxima in Greece determined based on glacier climate relationships at modern glacier ELAs [6]. Climate at the equilibrium line altitude (ELA) of glaciers during the glacier maximum of the Tymphian Stage (MIS 5d-2) is indicated at point a [19]. Climate at the ELA of glaciers during the glacier maximum of the Vlasian Stage (MIS 6) is indicated at point $b$. Climate possibilities at the ELA of glaciers during the glacier maximum of the Skamnellian Stage (MIS 12) are indicated by the heavy lined curve (c). The Tymphian and Vlasian glaciers formed under conditions analogous with modern maritime glaciers [wet and cold], whilst the Skamnellian Stage glaciers formed under more continental conditions [dry and cold]. The estimated modern climate is also shown for comparative purposes and is based on extrapolations of temperatures from Ioannina meteorological station (484 m a.s.1.) based on the 1961-1990 period [20].

glaciation in the Pindus Mountains occurred prior to the last interglacial during the Vlasian Stage (MIS 6). Glaciations may also have taken place during MIS 8 or 10 but their deposits have not been preserved, since later glaciations were more extensive. The most recent glaciation was much smaller in extent than the Middle Pleistocene glaciations and took place during the last cold stage of the Late Pleistocene - the Tymphian Stage (MIS 5d-2).

The aim of this paper is to utilise geomorphological and geochronological evidence of glaciations in the Pindus Mountains, Greece [4], to reconstruct summer temperature and annual precipitation combinations for the two Middle Pleistocene cold stages. The Middle Pleistocene glaciations were the most extensive glaciations recorded in Greece (Fig. 1) and excellent preservation of the geomorphological record has allowed detailed reconstruction of past glacier-climate conditions. This is the first time such palaeoclimatic parameters have been reconstructed for the Middle Pleistocene cold stages in terrestrial Europe using glacial evidence.

\section{Methods}

Mount Tymphi (2497 m a.s.1.) in northwest Greece provides the focus for palaeoclimatic reconstructions in this paper, as detailed investigations of the glacial record have recently been completed [4]. This evidence provided the basis for the three dimensional reconstruction of former glaciers using an approach similar to that outlined in Sissons [14,15]. Ice depth/surface slope relations were adjusted to conform to realistic flow 
characteristics suggested by glaciological theory [16]. Equilibrium line altitudes (ELA) were reconstructed by choosing the lowest standard deviation at a range of accumulation area ratios (AAR) between 0 and 1 for groups of glaciers [17]. An AAR of 0.6 was found to be most suitable for the Mount Tymphi glaciers, in agreement with other studies of mountain glaciers [18]. Summer temperature and mean annual precipitation combinations at the ELA of reconstructed former glaciers were calculated using a polynomial regression which relates temperature and precipitation at the ELA of 72 modern glaciers worldwide [6].

\section{Glacier-climate reconstructions}

Cirque glaciers covered an area of $3.9 \mathrm{~km}^{2}$ and rock glaciers $1.61 \mathrm{~km}^{2}$ on Mount Tymphi during the Tymphian Stage (MIS 5d-2). Summer temperatures at the Tymphian Stage glacier maximum have been reconstructed at $c .4 .9{ }^{\circ} \mathrm{C}$ (a depression of $-8.5{ }^{\circ} \mathrm{C}$ compared with modern values) and mean annual precipitation at c. $2300 \mathrm{~mm} \pm 200 \mathrm{~mm}$ using a combination of periglacial and glacial evidence [19]. The local glacier maximum is likely to have preceded the global glacial maximum and the most severe cold and arid phase of the Tymphian Stage. Glaciers are likely to have advanced during intermediate conditions characterised by cold and wet climates between major interstadials and stadials and at least 10 such intervals have been identified as being favourable for glacier advance and retreat can in pollen and sea surface temperature records for this cold stage [19]. Climate during earlier, more extensive Middle Pleistocene glacier maxima can be calculated relative to Tymphian Stage glacier-climate conditions.

In total, 14 glaciers on Mount Tymphi covered an area of $21.3 \mathrm{~km}^{2}$ with a mean ELA of $1862 \mathrm{~m}$ a.s.l. during the Vlasian Stage (MIS 6) (Fig. 1, Table 1). The lower ELAs compared with the Tymphian Stage can be attributed to lower summer temperatures and/or higher precipitation. If the lower and more extensive glaciers were the result of lower temperatures, and not increased precipitation, then a $312 \mathrm{~m}$ reduction in ELA [Tymphian Stage ELA (2174 m) — Vlasian Stage ELA (1862 m)] implies a summer temperature depression of $c .-1.9^{\circ} \mathrm{C}$ compared with the Tymphian Stage glacier maximum, assuming a standard atmospheric lapse rate of $0.6^{\circ} \mathrm{C}$ per $100 \mathrm{~m}$. Conversely, if the lower glacier ELAs were the result of higher annual precipitation, and not lower temperatures, then the $312 \mathrm{~m}$ difference in ELAs indicates that summer temperature was $1.9^{\circ} \mathrm{C}$ higher at the Vlasian Stage ELA. A summer temperature of
$6.8{ }^{\circ} \mathrm{C}$ [Tymphian Stage summer temperature at the ELA $\left(4.9^{\circ} \mathrm{C}\right)+$ temperature difference at lower Vlasian stage ELA $\left(1.9^{\circ} \mathrm{C}\right)$ ] suggests that mean annual precipitation was c. $3074 \pm 200 \mathrm{~mm}$ at the ELA of the Vlasian glaciers, $774 \mathrm{~mm}$ (34\%) higher than the value reconstructed for the ELA of the Tymphian glaciers.

The most extensive glaciers of the Pleistocene that reached the lowest elevations on Mount Tymphi formed during the Skamnellian Stage (MIS 12). In total, 15 glaciers covered an area of $59.3 \mathrm{~km}^{2}$ with a mean ELA of c. $1741 \mathrm{~m}$ a.s.l. (Fig. 1, Table 1). The Skamnellian Stage glaciers were $433 \mathrm{~m}$ lower than during the Tymphian Stage and $121 \mathrm{~m}$ lower than during the Vlasian Stage (Table 1). This must have been the result of lower summer temperatures and/or higher precipitation. If the most extensive glaciers were the result of lower temperatures, and not increased precipitation, then a $433 \mathrm{~m}$ reduction in ELA [Tymphian Stage ELA (2174 m) - Skamnellian Stage ELA $(1741 \mathrm{~m})$ ] implies a temperature depression of c. $-2.6{ }^{\circ} \mathrm{C}$ compared with the Tymphian Stage glacier maximum, assuming a standard atmospheric lapse rate of $0.6{ }^{\circ} \mathrm{C}$ per $100 \mathrm{~m}$. This implies a depression of summer temperatures by $-11.1{ }^{\circ} \mathrm{C}$ compared with today, since temperatures were depressed by $-8.5{ }^{\circ} \mathrm{C}$ compared to today during the Tymphian Stage. Conversely, if the lower glacier ELAs were the result of higher annual precipitation and not lower temperatures, then the $433 \mathrm{~m}$ difference in ELAs indicates that summer temperature was $2.6{ }^{\circ} \mathrm{C}$ higher at the Skamnellian Stage ELA. A summer temperature of $7.5^{\circ} \mathrm{C}$ [Tymphian Stage summer temperature at the ELA $\left(4.9^{\circ} \mathrm{C}\right)+$ temperature difference at lower Skamnellian stage ELA $\left.\left(2.6^{\circ} \mathrm{C}\right)\right]$ would have required mean annual precipitation of $c .3371 \pm 200 \mathrm{~mm}$ at the ELA of the Skamnellian glaciers, $1071 \mathrm{~mm}(47 \%)$ higher than the value reconstructed for the ELA of the Tymphian glaciers.

\section{Discussion}

It is clear that during the most extensive Skamnellian Stage glaciation (MIS 12), climate would have been even colder and/or wetter than was the case for both the later Vlasian and Tymphian cold stages. In the long pollen record at Tenaghi Philippon in northeast Greece, the interval correlated with MIS 12 was one of the most severe of the Pleistocene [13]. Moisture supply would have been reduced compared with interglacial conditions and the severity of this glacial cycle in the pollen record suggests that it would have been at least as dry as the last cold (Tymphian) stage. Thus, given that mean summer temperatures were depressed by $c .8 .5{ }^{\circ} \mathrm{C}$ relative to today during the Tymphian Stage [19], summer 
temperatures during the Skamnellian Stage would have been depressed by at least $11.1{ }^{\circ} \mathrm{C}$ with mean summer temperatures of $\leq 4.9^{\circ} \mathrm{C}$ at an altitude of $1741 \mathrm{~m}$ a.s.l., the glacier ELA. This would have been in combination with mean annual precipitation of $\leq 2300 \pm 200 \mathrm{~mm}$ (Fig. 2) and represents the coldest mean summer temperatures recorded in Greece during at least the last 430000 years.

During the Skamnellian Stage glacier maximum, climate at lower altitude sites such as Ioannina (484 m a.s.l. - altitude of the modern meteorological station), would have been characterised by mean summer temperatures of $\leq 12.4{ }^{\circ} \mathrm{C}$. Mean winter temperatures $(\mathrm{Dec} / \mathrm{Jan} / \mathrm{Feb})$ are likely to have been at least $-0.8{ }^{\circ} \mathrm{C}$ when a temperature depression of $11.1^{\circ} \mathrm{C}$ is applied to the modern range and distribution of temperatures [20]. Given that lower sea levels during cold stages [21] and extensive glaciation in the Balkans would have contributed to more continental conditions than today, mean winter temperatures are likely to have significantly less than $-0.8{ }^{\circ} \mathrm{C}$. This harsh climate would have enhanced periglacial frost shattering of bedrock over large areas of the Pindus Mountains and increased sediment delivery to river systems [22]. An intermediate altitudinal climatic zone between very dry lowland and severely cold highland areas would have been greatly narrowed compared with later glacial stages.

The climate at the Vlasian Stage (MIS 6) glacier maximum is likely to have been colder and/or wetter than at the equivalent event of the later Tymphian Stage. The high resolution isotopic record from speleothems at Soreq Cave in Israel has shown that throughout MIS 6, the Eastern Mediterranean was as cold as much of the last glacial (Tymphian), but conditions were never as dry [23]. Evidence for humid conditions during MIS 6 are also found in the Western Mediterranean in the $\delta^{18} \mathrm{O}$ record from a stalagmite in a cave on the Tyrrhenian coast of Italy. Increased precipitation between $180 \mathrm{ka}$ and $170 \mathrm{ka}$ is thought to have been responsible for the dilution of sea water across the Mediterranean and the $\delta{ }^{18} \mathrm{O}$ stalagmite record in Italy has been correlated with the cold sapropel event 6 in the Mediterranean Sea [24]. Thus, the larger glaciers of the Vlasian (compared with the Tymphian) may have been the product of greater precipitation and not lower summer temperatures, in direct contrast to the situation during the Skamnellian Stage. Under these circumstances, the climate at the Vlasian mean glacier ELA (1862 m a.s.l.) would have been characterised by mean summer temperatures of $c$. $6.8{ }^{\circ} \mathrm{C}\left[8.5{ }^{\circ} \mathrm{C}\right.$ lower than today $]$ and annual precipitation of $3074 \pm 200 \mathrm{~mm}$ (Fig. 2).

\section{Conclusions}

The coldest mean summer temperatures of the last 427000 years forced the most extensive recorded glaciation in Greece. At the local glacier maximum during MIS 12 (474000-427000 years BP), climatic conditions were characterised by mean summer temperatures at least $11{ }^{\circ} \mathrm{C}$ cooler than today and annual precipitation of $\leq 2300 \mathrm{~mm}$ at the equilibrium line altitude (1741 m a.s.l.). Later Pleistocene glaciations (MIS 6 and 5d-2) were characterised by warmer summer temperatures and higher annual precipitation and glaciations that were progressively smaller in extent.

\section{Acknowledgements}

PDH was funded by a University of Cambridge Domestic Research Studentship (2001-2004) and a University of Manchester Research Fellowship (20042006). Uranium-series support was provided by NERC (Reference Number: IP/754/0302) and undertaken at the Open University Uranium Series Facility in Milton Keynes. All field work was undertaken with permission of the Institute of Geological and Mineral Exploration (IGME) of Greece. We are grateful to the reviewers and to Professor Harry Elderfield for helpful comments, which improved this paper.

\section{References}

[1] G.W. Smith, R.D. Nance, A.N. Genes, Quaternary glacial history of Mount Olympus, Geol. Soc. Amer. Bull. 109 (1997) 809-824.

[2] A. Çiner, Turkish glaciers and glacial deposits, in: J. Ehlers, P.L. Gibbard (Eds.), Quaternary Glaciations - Extent and Chronology. Part I, Elsevier, Europe, 2004, pp. 419-429.

[3] J.C. Woodward, M.G. Macklin, G.R. Smith, Pleistocene glaciation in the mountains of Greece, in: J. Ehlers, P.L. Gibbard (Eds.), Quaternary Glaciations - Extent and Chronology. Part I, Elsevier, Europe, 2004, pp. 155-173.

[4] P.D. Hughes, J.C. Woodward, P.L. Gibbard, M.G. Macklin, M.A. Gilmour, G.R. Smith, The glacial history of the Pindus Mountains, Greece, J. Geol. 114 (2006) 413-434.

[5] P.D. Hughes, J.C. Woodward, P.L. Gibbard, Quaternary glacial history of the Mediterranean mountains, Prog. Phys. Geogr. 30 (2006) 334-364.

[6] A. Ohmura, P. Kasser, M. Funk, Climate at the equilibrium line of glaciers, J. Glaciol. 38 (1992) 397-411.

[7] G.M. Hewitt, Postglacial recolonization of European Biota, Biol. J. Linn. Soc. 68 (1999) 87-112.

[8] J. Blondel, J. Aronson, Biology and Wildlife of the Mediterranean, Oxford University Press, 1999.

[9] H.I. Griffiths, B. Kryštufek, J.M. Reed (Eds.), Balkan Biodiversity: Pattern and Process in the European Hotspot, Kluwer Academic Publishers, 2004. 
[10] P.C. Tzedakis, Long-term tree populations in northwest Greece through multiple Quaternary climatic cycles, Nature 364 (1993) 437-440.

[11] F.E. Bassinot, L.D. Labeyrie, G. Vincent, X. Quidelleur, N.J. Shackleton, Y. Lancelot, The astronomical theory of climate and the Brunhes-Matuyama magnetic reversal, Earth Planet. Sci. Lett. 126 (1994) 91-108.

[12] J. Ehlers, Quaternary and Glacial Geology, Wiley, Chichester, 1996, $578 \mathrm{pp}$.

[13] P.C. Tzedakis, J.F. McManus, H. Hooghiemstra, D.W. Oppo, T.A. Wijmstra, Comparison of changes in vegetation in northeast Greece with records of climate variability on orbital and suborbital frequencies over the last 450000 years, Earth Planet. Sci. Lett. 212 (2003) 197-212.

[14] J.B. Sissons, The Loch Lomond Advance in the Northern Mainland of Scotland, in: J.M. Gray, J.J. Lowe (Eds.), The Scottish Lateglacial Environment, Pergamon Press, 1977.

[15] J.B. Sissons, A Late-glacial ice-cap in the central Grampians, Scotland, Trans. Inst. Br. Geogr. 62 (1974) 95-114.

[16] W.S.B. Paterson, The Physics of Glaciers, 3rd edition, Pergamon, 1994.

[17] G. Kaser, H. Osmaston, Tropical Glaciers, Cambridge University Press, 2004, pp. 149-192.

[18] S.C. Porter, Equilibrium-line altitudes of late Quaternary glaciers in the Southern Alps, New Zealand, Quat. Res. 5 (1975) 27-47.

[19] P.D. Hughes, J.C. Woodward, P.L. Gibbard, Late Pleistocene Glaciers and climate in the Mediterranean region, Glob. Planet. Change 50 (2006) 83-98.
[20] World Meteorological Organisation, 1961-1990 global climate normals. Electronic resource. National Climatic Data Center, US. Asheville, NC. (CD-ROM) 1998.

[21] Y. Yokoyama, K. Lambeck, P. De Deckker, P. Johnston, K. Fifield, Timing of the Last Glacial Maximum from observed sea-level minima, Nature 406 (2000) 713-716.

[22] J.C. Woodward, J. Lewin, M.G. Macklin, Alluvial sediment sources in a glaciated catchment: the Voidomatis basin, northwest Greece, Earth Surf. Process. Landf. 16 (1992) 205-216.

[23] A. Ayalon, M. Bar-Matthews, A. Kaufman, Climatic conditions during marine isotope stage 6 in the eastern Mediterranean from the isotopic composition of speleothems of Soreq Cave, Geology 30 (2002) 303-306.

[24] E. Bard, G. Delaygue, F. Rostek, F. Antonioli, S. Silenzi, D.P. Schrag, Hydrological conditions over the western Mediterranean during the deposition of the cold sapropel 6 (ca. $175 \mathrm{kyr}$ BP), Earth Planet. Sci. Lett. 202 (2002) 481-494.

[25] R.H.B. Hamlin, J.C. Woodward, M.G. Macklin, S. Black, Sediment fingerprinting as a tool for interpreting long-term river activity: the Voidomatis basin, Northwest Greece, in: I.D.L. Foster (Ed.), Tracers in Geomorphology, John Wiley and Sons, Chichester, 2000, pp. 473-501.

[26] R.H.B. Hamlin, Environmental change and catastrophic flooding in the Voidomatis and Aoos basins, Northwest Greece, PhD thesis, University of Leeds, 299 pp. 